

\title{
The Use of Swot Analysis Method to Promote Aesthetic Appreciation of Graphic Novel Among Year 5 Intermediate Proficiency Pupils
}

Serdev Singh, Azlina Abdul Aziz

To Link this Article: http://dx.doi.org/10.6007/IJARBSS/v10-i6/7387

DOI:10.6007/IJARBSS/v10-i6/7387

Received: 24 April 2020, Revised: 29 May 2020, Accepted: 06 June 2020

Published Online: 19 June 2020

In-Text Citation: (Singh \& Aziz, 2020)

To Cite this Article: Singh, S., \& Aziz, A. A. (2020). The Use of Swot Analysis Method to Promote Aesthetic Appreciation of Graphic Novel Among Year 5 Intermediate Proficiency Pupils. International Journal of Academic Research in Business and Social Sciences, 10(6), 899-908.

\section{Copyright: (C) 2020 The Author(s)}

Published by Human Resource Management Academic Research Society (www.hrmars.com)

This article is published under the Creative Commons Attribution (CC BY 4.0) license. Anyone may reproduce, distribute, translate and create derivative works of this article (for both commercial and non-commercial purposes), subject to full attribution to the original publication and authors. The full terms of this license may be seen at: http://creativecommons.org/licences/by/4.0/legalcode

Vol. 10, No. 6, 2020, Pg. 899 - 908

Full Terms \& Conditions of access and use can be found at http://hrmars.com/index.php/pages/detail/publication-ethics 


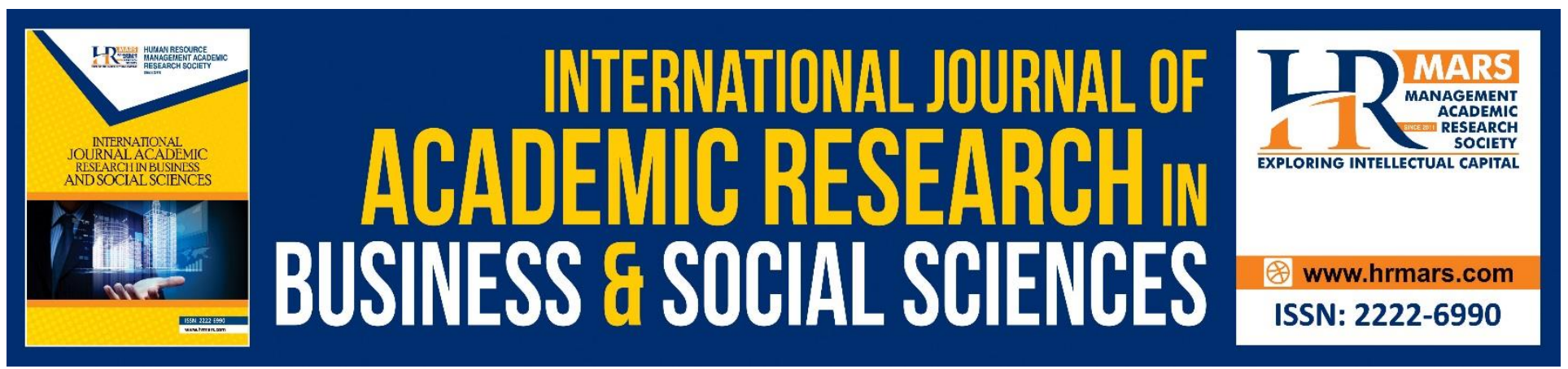

\title{
The Use of Swot Analysis Method to Promote Aesthetic Appreciation of Graphic Novel Among Year 5 Intermediate Proficiency Pupils
}

\author{
Serdev Singh \\ Faculty of Education, Universiti Kebangsaan Malaysia \\ Email: serdevsingh@gmail.com
}

Azlina Abdul Aziz

Centre of Innovation in Teaching \& Learning, Faculty of Education, Universiti Kebangsaan Malaysia

Email: azlina1@ukm.edu.my

\begin{abstract}
The purpose of this action research is to promote and determine the effectiveness of the SWOT analysis method in helping Year 5 intermediate proficiency pupils to analyse the characters in the literary text of the graphic novel 'Gulliver's Travel'. The participants in this study consisted of twentysix pupils from one of the national schools in Bintulu, Sarawak. The research instruments consist of tests, interviews and observations. This research was conducted during English language lesson where both conventional and intervening lesson was carried out. Test 1 and Test 2 were conducted in order to collect the data. The test results showed that the majority of the participants' score has significantly improved in Test 2. This shows that the SWOT analysis method is effective in helping Year 5 intermediate proficiency pupils in analyzing and connecting themselves with the characters in the literary text as compared to the conventional teaching method. Similarly, the results from the interviews and observations also indicated that there was a significant improvement reflected through the data gathered from the conventional lesson.
\end{abstract}

Keywords: Literary Text, Character, Analyse, Swot Analysis, Aesthetic.

\section{Introduction}

In Malaysia, the English language has the status of a second language (Darus, 2010). In the field of education, the English language is actively and extensively used from the primary up to tertiary level (Izwan \& Lina, 2010). Malaysia also has been fixating towards the growth and expansion of the education system. This is to ensure every child gets an equal access to education. The English subject was introduced for both primary and secondary pupils as a second language (hereafter ESL). The goal of the English language curriculum is to guide pupils to master and be competent in the language. The teaching of the language, on the other hand, consists of the four main language skills 
INTERNATIONAL JOURNAL OF ACADEMIC RESEARCH IN BUSINESS AND SOCIAL SCIENCES

Vol. 10, No. 6, June, 2020, E-ISSN: 2222-6990 @ 2020 HRMARS

which are listening, speaking, reading and writing. According to Ministry of Education (hereafter Moe) (2010), the English curriculum aims to enhance learners; competence of the language which in return would assist them for their future goals. In other words, pupils are expected to use the language effectively in the future to further enhance the communication process.

\section{Research Focus}

According to Alghazo (2015), it is best to emphasise the teaching of literature at the early stages of second language acquisition. Thus, the language arts module has been introduced to pupils in Primary 5 to be taught to pupils in primary schools (MOE, 2013). According to the MOE (2012), English is regarded as a second language in all schools. MOE has introduced the new education system which is the Standard Curriculum for Primary School (KSSR). It is structured in the modular structure which consisted of five modules. The skills embedded in the modules are listening and speaking, reading, writing, language arts and grammar (MOE 2001; 2013).

Through these modules, the literature component is given attention through the children's contemporary literature. It is seen as one of the integral parts in teaching and learning of the English language by embedding the language arts module in the English syllabus. According to MOE (2012), pupils are introduced to various kinds of genres through language arts modules. The genres include poem, children short story, and graphic novel. In order to be proficient in the English language, one cannot focus mainly on the four main skills which are as listening, speaking, reading, and writing. It is crucial to introduce literature in English classrooms.

This would indirectly train pupils to apply the knowledge learnt to stimulate their thoughts. The MOE (2012) stated that through the language arts modules, students are given a platform to engage themselves in various kinds of literary works. MOE (2012) further added that pupils' imagination, interest, and creativity could be further enhanced through this module. Therefore, in other words, the language arts module aims to develop pupils' ability to achieve personal development in order to function as effective members in the society.

\section{Research Questions}

This study was guided by the following research questions:

i. How can the SWOT analysis method be used to analyse the characters in the literary text?

ii. How can the SWOT analysis method be used to help pupils to make connections with the characters in the literary text?

\section{Literature Review}

\section{Graphic Novels in Malaysian ESL Classrooms}

According to Suriani, Zalina, and Khazriyati (2017), graphic novel was introduced in Malaysian primary school since 2011. It is a genre which is embedded in the language arts module. It is believed that the Ministry of Education's (MOE) decision to introduce graphic novels is a ticket for Malaysian pupils to think creatively to oppose the old school mind set of rot learning. One of the most logical benefits of using graphic novels in the classroom is to motivate pupils to read.

Agnes (2018) mentioned that students' personal development and individual skill could be polished when they combine both literary text and images to create a meaning. This would indirectly guide the pupils to delve into a story or put the characters' situation in their shoe. Agnes further added a creative process could be created in learning when students could analyse the story based 
on the elements such as the characters' feelings and needs. As reiterated by McCloud (1993), the process of reading a graphic novel involves the construction of meaning, languages used, visual details, facial expression, the size of the words and shading. These details in graphic novels indirectly could help readers to reflect on the characters thus think independently and creatively instead of reading for mere pleasure.

\section{The Underlying Theories of Using SWOT Analysis}

One of the theories which are pertinent to the SWOT analysis in this study is Bloom's Taxonomy. Bloom's Taxonomy aims is to enhance higher order thinking among students such as to analyse and evaluate. This is very much different than the lower order thinking strategy which is expecting students to merely understand and remember facts. In the taxonomy, students' learning process are evaluated according to degrees of difficulties which comprised of six main categories. In other words, students must master the first category before moving to the next.

In order to promote creative and critical thinking skills in the literature classroom, the elements of Higher Order Thinking Skills (HOTs) are brought in. According to King, Goodson and Faranak (2000), these elements consist of creative, critical, metacognitive, reflective and logical thinking. Thus, elements such as applying, analysing, and predicting as mentioned in the hierarchy of Bloom's Taxonomy were used by the research participants when they were collaborating with one another.

\section{Reader Response Theory}

According to Anderson (2012), Rosenblatt's transactional theory describes the relationship between readers and literary texts in order to create a new meaning. Richard (1993) mentioned that the term transaction was adopted based on Dewey's writing which mentioned that in the process of reading, both reader and text are responsive. Cox (2014) asserted that the in Reader Response Theory (hereafter RRT), the focus is shifted from evaluating the text on surface level to understanding how readers engage themselves in the process of constructing meaning while reading a literary text.

Rosenblatt's theory of transaction determines the stance a reader might fall into. According to Anderson (2012), when a person reads, there are two options on where he might fall on a continuum which is either 'efferent' or 'aesthetic' stance. In aesthetic stance, a reader would relate to his experience, emotions in order to make a connection with the text, whereas in the efferent stance, a reader reads with the purpose to retain information (Rosenblatt, 2005). In efferent stance, the primary aim is to extract information which is to be used after the reading process. The emphasis of reading is like that given on factual materials such as books, newspaper, and others. On the other side of the continuum, a reader place attention of his feeling when an aesthetic stance takes place.

\section{Methodology}

\section{Research Participants}

The participants of this study consisted of twenty-six pupils from class $5 \mathrm{X}$ in a national primary school in Bintulu, Sarawak. The pupils in class 5X are not streamed based on their academic performance. This is the rationale for class $5 X$ consisting of pupils with the mixed ability level of proficiency. 
INTERNATIONAL JOURNAL OF ACADEMIC RESEARCH IN BUSINESS AND SOCIAL SCIENCES Vol. 10, No. 6, June, 2020, E-ISSN: 2222-6990 @ 2020 HRMARS

\section{Action Taken}

In this study, two lessons were conducted. For the conventional lesson, the teacher (researcher) played a picture puzzle game with the participants during the set induction stage. During the prereading stage, the teacher introduced the necessary vocabulary with the aid of picture and word cards. The participants read the graphic novel 'Gulliver's Travel' in chapter 1 and answered a task sheet individually during the while-reading stage. Then, they performed a 'role play' during the postreading stage. Teacher consolidated the lesson during the closure stage.

As for the intervening lesson, during set induction stage, the teacher entered the class by dressing up as one of the characters in the literary text, which was Gulliver and introduced himself. Teacher probed the participants by asking questions. During the pre-reading stage, the teacher introduced vocabulary with the aid of picture and word cards. As for the while reading stage, the participants read the graphic novel 'Gulliver's Travel' on chapter 5 and filled in the Strength, Weakness, Opportunity and Threat (hereafter SWOT) table in pairs. Then, they formed a group of five and carried out a group discussion by sharing their views and opinions based on what has been written on their SWOT table during the post-reading stage. Teacher consolidated the lesson during the closure stage.

\section{Research Findings}

All the data from the different instruments were gathered, and the results of the conventional teaching method with the comparison to the implementation of SWOT Analysis method in the classroom were analysed. The data comprised of tests, interviews and observations.

\section{Research Question 1}

The performance of the participants both in Test 1 and 2 was also compared. The data presented in Table 1 was based on a scale of levels of achievement and its pre-requisite scores. The scale ranges from Grades A (90-100 marks), B (70 - 89 marks), C (50-69 marks), D (40-49 marks) and E (0-39 marks).

Table 1: Analysis of the participants' performance in Test 1 and Test 2

\begin{tabular}{|c|c|c|c|c|}
\hline \multirow{2}{*}{$\begin{array}{c}\text { Grade of Achievement \& } \\
\text { Scores }\end{array}$} & \multicolumn{2}{|c|}{ Test 1} & \multicolumn{2}{|c|}{ Test 2} \\
\hline & $\%$ & $\begin{array}{l}\text { No. of } \\
\text { RP }\end{array}$ & $\%$ & $\begin{array}{l}\text { No. of } \\
\text { RP. }\end{array}$ \\
\hline A & $90-100$ & 6 & $90-100$ & 21 \\
\hline B & $70-89$ & 15 & $70-89$ & 4 \\
\hline$C$ & $50-69$ & 4 & $50-69$ & 1 \\
\hline D & $40-49$ & 1 & $40-49$ & - \\
\hline$E$ & $0-39$ & - & $0-39$ & - \\
\hline TOTAL & 100 & 26 & 100 & 26 \\
\hline
\end{tabular}


The data revealed that in Test 1, none of the participants (0\%) obtained Grade E. however, there was one participant (3.8\%) who obtained Grade D. Meanwhile, there were four participants (15.9) who got Grade C. Majority of the participants (57.7\%) achieved Grade B while only six participants (23\%) got Grade A. In Test 2 however, the data was more convincing. A total of twentyone participants (80.8\%) were able to obtain Grade A. This is then followed by four participants (15.9\%) who attained Grade B whereas the remaining one participant (3.8\%) managed to get Grade C. There were no participants who scored lower than Grade C in Test 2. Based on the data, it can be inferred that participants performed better in Test 2 as compared to Test 1.

Furthermore, the results are also supported by findings from the interviews. For the intervening lesson, the following were the responses of the participants to the question in the interview:

Question 2: What do you think is important in this chapter? Why?

\begin{tabular}{|c|c|}
\hline After Test 2 & \\
\hline Participant A & $\begin{array}{l}\text { The important is teamwork and hardworking because he ... } \\
\text { because they escape. If I am Gulliver, I will never give up and still } \\
\text { escape. }\end{array}$ \\
\hline Participant B & $\begin{array}{l}\text { Hardworking. Because it will help many people. Erm... if I'm } \\
\text { Gulliver, I will make boat. And... *pause* }\end{array}$ \\
\hline Participant C & $\begin{array}{l}\text { The important is teamwork in the ship because they are in } \\
\text { dangerous. For example... *flipping pages*.. Page } 7 \text {. The ship } \\
\text { down. They never give up. If I'm Gulliver, I will... I will pray to God. }\end{array}$ \\
\hline Participant D & $\begin{array}{l}\text { Erm... teamwork. Because Gulliver and the crew work together to } \\
\text { row the boat against the big wave. }\end{array}$ \\
\hline Participant E & $\begin{array}{l}\text { The important is teamwork. Gulliver will row the boat. If I am } \\
\text { Gulliver, I will be very sad. }\end{array}$ \\
\hline Participant F & Teamwork. If my friend need a help, I help they. \\
\hline Participant G & $\begin{array}{l}\text { They used boat to save their lives. Because they don't want to die? } \\
\text { Because they want to go to another island }\end{array}$ \\
\hline Participant H & $\begin{array}{l}\text { The important is Gulliver is so brave and strong because he is } \\
\text { patient man. He... he... *flipping pages*... his ship was cracked and } \\
\text { he still patient. }\end{array}$ \\
\hline Participant I & $\begin{array}{l}\text { Never give up. *pause*... if I am Gulliver, I will never give up } \\
\text { because I am a never give up person. }\end{array}$ \\
\hline Participant J & $\begin{array}{l}\text { I think important in this chapter is teamwork. If I am Gulliver, and } \\
\text { the situation happened to me, I will protect my friends and... *long } \\
\text { pause*... }\end{array}$ \\
\hline
\end{tabular}

Question 2 was asked to the selected participants. It was found that the participants seemed to be quite clueless and lost when the question was asked during an interview after test 1 was conducted. Compared to Test 2 , they were seen to be more responsive as if a different question was asked. When asked what they thought was important in chapter 1 in Test 1, most of the participants were quiet and were unable to answer the question. In the second interview which was carried out after Test 2, nevertheless, most of them found it easier and were able to answer the question. They were able to provide references from the graphic novel by mentioning the traits possessed by the 
INTERNATIONAL JOURNAL OF ACADEMIC RESEARCH IN BUSINESS AND SOCIAL SCIENCES Vol. 10, No. 6, June, 2020, E-ISSN: 2222-6990 @ 2020 HRMARS

characters in the literary text. This proves that the 'SWOT analysis method has helped them to gain a better understanding of the story thus being able to analyse the characters in the literary text.

It is important to highlight that the questions in both Test 1 and Test 2 were of the same level. Thus, this reflects that the participants have improved because they were able to answer questions in Test 2 as compared with the ones in Test 1.

\section{Research Question 2}

To further analyse the findings collected in the tests, they were also reviewed in terms of the participants' responses between efferent and aesthetic stance. As mentioned in chapter three, the instrument adapted by Broders (2000) from the instrument for Measuring Reader Stance designed by Cox and Many (1992) was applied to categorise the participants' stances.

It is observed that there is a significant difference between the participants' aesthetic stance in Test 2 as compared to that of Test 1 . In Test 1, the participants' aesthetic stance was made up of only $31 \%$ while in Test 2, the percentage increased by twice the amount of Test 1 which is $69 \%$. As for the responses of efferent stance, the percentage reduced drastically from Test 1 to Test 2 which were from $69 \%$ to $25 \%$. These figures, in a way, shows that the participants managed to move along the continuum, from efferent to aesthetic stance, as suggested by Rosenblatt.

In order to determine the participants' stances using the 'SWOT analysis' method, they were interviewed until a saturation point was reached. Their responses were transcribed, coded and categorised to determine emerging themes (reasons). From the analysis, the data is presented below in Table 2.

Table 2 Emerging themes from the interview data.

\begin{tabular}{llcc}
\hline Num. & Categories of themes & Frequency & Percentage(\%) \\
\hline $\mathbf{1}$ & Putting into characters' shoes & 11 & 10.7 \\
$\mathbf{2}$ & Feeling & 21 & 20.4 \\
$\mathbf{3}$ & Desire & 24 & 23.3 \\
$\mathbf{4}$ & Traits & 36 & 34.9 \\
$\mathbf{5}$ & Text accuracy & 11 & 10.7 \\
\hline \multicolumn{2}{r}{ Total } \\
\hline
\end{tabular}

From Table 2, five main themes were identified from the interviews that had been carried out with the ten participants. The theme with the highest frequency is 'traits' with a percentage of 34.9\%, followed by the second theme, which is 'desire' with a percentage of $23.3 \%$. This was closely followed by the third theme, which is 'feeling' with the percentage of $20.4 \%$. The fourth and fifth theme, which are putting into characters' shoe' and 'text accuracy' shares the same percentage, which is $10.7 \%$. Each theme is comprised of the elements which belong from the same category.

The theme with the highest frequency, which is 'traits' was mentioned 36 times. The second highest theme is 'desire' was mentioned 24 times. The following theme is 'feeling'. It was mentioned 21 times. The data in Table 2 also revealed the two emerging themes with the same frequency, which is 11 . The theme 'putting into characters' shoes' and 'text accuracy' was mentioned 11 times. 


\section{Discussions}

It is noticed that the participants learnt and performed better when the intervention, SWOT analysis method was employed. They were explicitly able to both analyse and make connections with the characters in the literary text. In the intervening lesson, it was noticed that the participants demonstrated active participation during the group discussion. They were motivated to complete the given task which was filling in the SWOT table individually and then proceeded to group discussion. It is also observed that they enjoyed the learning process when they are given the platform to interact with their friends.

When giving aesthetic stance, most participants would describe the characters using the traits that they possessed and would eventually associate themselves using these traits based on their feelings and personal experience. This indicates that the intervention strategy, which is the 'SWOT analysis' method helped them to internalise the characters and the story plot of the graphic novel 'Gulliver's Travel'. According to Rabah (2010), research by Ali in the year 1993 presented that students learned to believe and accept their peers' views and opinions through discussions. The researcher added that the participants also benefit from the literary texts by understanding the importance of aesthetic values from the text. Thus, these values are appreciated by them as active readers

A study by Galda allowed her to explore how children share their different opinions in small group discussion activities (Galda, 2013). She added that the research showed her how interesting small group discussions could be and that there seemed to be a range of ways to read aesthetically and approach a text thus guiding them to answer questions which adult learners might find difficult. In this study, it is also noticed that the participants were able to share their ideas and opinion during the group discussion effectively

\section{Recommendation}

It was found that participants who are of either weak or intermediate proficiency cannot fully maximise the use of the SWOT analysis method. This was because they cannot generate their ideas, thus being unable to articulate their thoughts comfortably. Therefore, the researcher intends to select participants who are proficient in the English language in the next cycle. With a good command of the English language, they will indirectly be able to articulate their thoughts and opinions among themselves. According to Sanchez (2010), when participants' proficiency levels are at par, it will enable them to adopt the changes in their opinion. Hence, it is felt that it is essential for the participants to have a good grasp of the English language.

Next, the researcher also intends to adapt the current SWOT table to higher level. In the next cycle, in each of the quadrants of the SWOT table, the numbers of questions will be reduced, and general questions will be asked. The rationale is to further tap on their thinking processes. According to Weinstein, McDermott and Roediger (2010), the learning process could be further enhanced when the rate of task involvement is developed to a higher level. Thus, it is believed that better engagement between learners and literary text could be created.

\section{Conclusion}

In conclusion, this research has strengthened my belief that as a competent researcher, I need to continually reflect on my teaching methods and seek solutions to overcome any challenges that I encounter in my teaching. The use of the SWOT analysis method has opened my mind and provided 
INTERNATIONAL JOURNAL OF ACADEMIC RESEARCH IN BUSINESS AND SOCIAL SCIENCES

Vol. 10, No. 6, June, 2020, E-ISSN: 2222-6990 @ 2020 HRMARS

me with an opportunity to apply the theories which I have never come across. This has created meaningful experiences that I could apply in the future, especially in the teaching and learning process in the classroom.

The findings of the study had contributed to the English language teaching fraternity. It is crucial for learners to actively engage and express their emotional reaction to make connections with the characters in literary texts. It is believed that the data from this study is beneficial in the ESL context primarily for young learners. With the incorporation of group discussion technique, it is believed that young learners will be moulded to be independent learners and thinkers.

\section{References}

Agnes, P. (2018). Art teaching and creative technologies: Interactive graphic novels foster thinking and artistic creation. International Journal of Learning, Teaching and Educational Research 17(6): 153-166.

Anderson, M. (2012). Reader response theories and life narratives. Retrieved from http://dtpr.lib.athabascau.ca/action

Broders, K. M. (2000). First graders' efferent and aesthetic responses to informational trade books. LSU Historical Dissertations and Theses. Retrieved from https://pdfs.semanticscholar.org/891a

Cox, C. (2014). Teaching language arts: A student-centered classroom. (7 ${ }^{\text {th }}$ Ed.). USA: Pearson Education Limited.

Cox, C., \& Many, J. (1992). Reader stance toward a literary work: Applying the transactional theory to children's responses. Reading Psychology, 13, 37-72.

Galda, L. (2013). Learning from children reading books: Transactional theory and the teaching of literature. Retrieved from http://www.childrensliterature.org

Rabah, H. A. (2010). Difficulties faced by English teachers in teaching literature in English for Palestine grade twelve textbook. Retrieved from http://library.iugaza.edu.ps/thesis/

Izwan, K., \& Lina, N. (2010). A study on second language speaking anxiety among UTM students. Retrieved from http://eprints.utm.my/10275

King, F. J., Goodson, L., \& Rohani, F. (2000). Higher order thinking skills. Retrieved from http://www.cala.fsu.edu/files/higherorder

McCloud, S. (1993). Understanding Comics: The invisible art. New York: Harper Collins.

Ministry of Education. (2001). Integrated primary school curriculum (KBSR). Malaysia: Curriculum Development Centre.

Ministry of Education. (2010). Integrated primary school curriculum (KBSR). Malaysia: Curriculum Development Centre.

Ministry of Education. (2012). Primary standard curriculum (KSSR) Year 4. Malaysia: Curriculum Development Centre.

Ministry of Education. (2013). Primary standard curriculum (KSSR) Year 4. Malaysia: Curriculum Development Centre.

Richard, B. (1993). A teacher's introduction to reader response theories. USA: National Council of Teachers of English.

Rosenblatt, L, M. (2005). Literature: S.O.S.! Voices from the Middle 12: 34-38. 
INTERNATIONAL JOURNAL OF ACADEMIC RESEARCH IN BUSINESS AND SOCIAL SCIENCES

Vol. 10, No. 6, June, 2020, E-ISSN: 2222-6990 @ 2020 HRMARS

Darus, S. (2010). The current situation and issues of the teaching of English in Malaysia. Ritsumeikan Studies in Language and Culture 22(1): 19-28.

Sanchez, F. (2010). Interactive classroom strategies \& structures for sucess: Focus on English learners. Retrieved from https://www.csustan.edu/sites/def

Alghazo, S. (2015). Advanced EFL learners' belief about pronunciation teaching. International Education Studies 8(1): 63-67. Retrieved from http://files.eric.ed.gov

Suriani, M. Y., Zalina. M. L., \& Khazriyati. S. (2017). Teacher trainees' perspectives of teaching graphic novels to ESL Primary Schoolers. 3L: The Southeast Asian Journal of English Language Studies 23(3): $81-96$.

Weinstein, Y., McDermott, K. B., \& Roediger H. L. (2010). A comparison study strategies for passages: Rrereading, answering questions, and generating questions. Journal of Experimental Psychology, 16(3), 308-316. 